\title{
Geotectonic setting of the Tertiary Uyandina and Indigirka-Zyryanka basins, Republic Sakha (Yakutia), Northeast Russia, using coal rank data
}

\author{
H.-J. Paech \\ Federal Institute for Geosciences and Natural Resources, Hannover, Germany \\ now retired
}

\begin{abstract}
Outcrops along the Inach River in the Uyandina basin and those along the Myatis' River in the IndigirkaZyryanka basin were studied in detail and sampled for coal rank determinations. The Uyandina basin is an intramontane pull-apart basin characterized by extensional structures within the Moma rift system. The coal rank is below $0.3 \%$ vitrinite reflectance $\left(R_{r}\right)$, which indicates shallow, immature conditions of basin formation and very low subsidence. The Myatis' River coal-bearing outcrops in the IndigirkaZyryanka basin reveal compression induced by continent collision. The compressive deformation includes also lowermost Pliocene strata. Due to the position in the VerkhoyanskChersky fold belt adjacent to the Kolyma-Omolon microcontinent the Indigirka-Zyryanka basin has much in common with a foredeep, i.e. the asymmetry in thickness and tectonic structure. The vitrinite reflectance data $\left(R_{r}\right)$ which range from $0.25 \%$ to more than $5 \%$ reinforce the accepted models that describe basin subsidence and geothermal history and the tectonic deformation.
\end{abstract}

\section{Introduction}

In Circum-Arctic regions Tertiary compressive tectonic structures are common (Svalbard, Northern Greenland, Ellesmere Island and Brooks Range in Alaska). The situation in Siberia was unclear. Thus, in 1998 the Federal Institute for Geosciences and Natural Resources (BGR) in Hannover (Germany) and the Institute of Geological Sciences of the Siberian Branch of the Russian Academy of Science, Sakha Republic, the Russian Federation, in Yakutsk organized the German-Russian Moma Rift Expedition within "Correlation of Alpine Structural Events" (CASE-3). The main objective

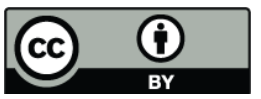

Correspondence to: H.-J. Paech

(hans.paech@arcor.de) of these studies was to determine whether Tertiary structures previously described by such authors as Imaev and Grinenko (1989), Imaev et al. (1990, 1994, 1998) and Smetannikova et al. (1989) within the Circum-Arctic region of the Asian Continent are compressional or extensional in origin. Preliminary results of the CASE- 3 expedition are given in Paech et al. (1998). This contribution provides more detailed field observations and improved coal rank determinations.

\section{Study methods}

Logistic restrictions limited our investigations to a few areas: 1) the escarpments of Inach River (Uyandina basin); 2) outcrops on the Myatis' River (Indigirka-Zyryanka basin); and 3) short observations in outcrops along the Nikandya River. During detailed examination of outcrops, 93 samples were collected (including 49 samples collected previously during Russian expeditions) for organic matter and coal rank determinations that were estimated by vitrinite reflectance $\left(R_{r}=\right.$ mean value $)$ measurements. In the BGR these studies were carried out using well known standard procedures (DIN 22020, part 5; ISO, part 5; Stach et al., 1982) for polished grains of the $<1 \mathrm{~mm}$ fraction. For comparison some of these samples were also studied in the Yakutsk (Russia) laboratories as well. Generally, the Russian vitrinite reflectance data (49 samples) of $R_{r}$ are slightly $(<0.1 \%)$ higher than the laboratory results obtained by the BGR. As illustrated in Fig. 1 the coal rank generally is linked with increasing temperatures of formation, however it can also be linked to tectonic structures. The coalification is associated with coeval compaction and dehydration of the sediments, mineral alteration and tectonic deformation. The higher the coal rank, the more intense is the deformation. Consequently, the formation of the cleavage occurs at depths in the Earth's crust with temperatures attaining at least $200^{\circ} \mathrm{C}$.

Published by Copernicus Publications on behalf of the European Geosciences Union. 


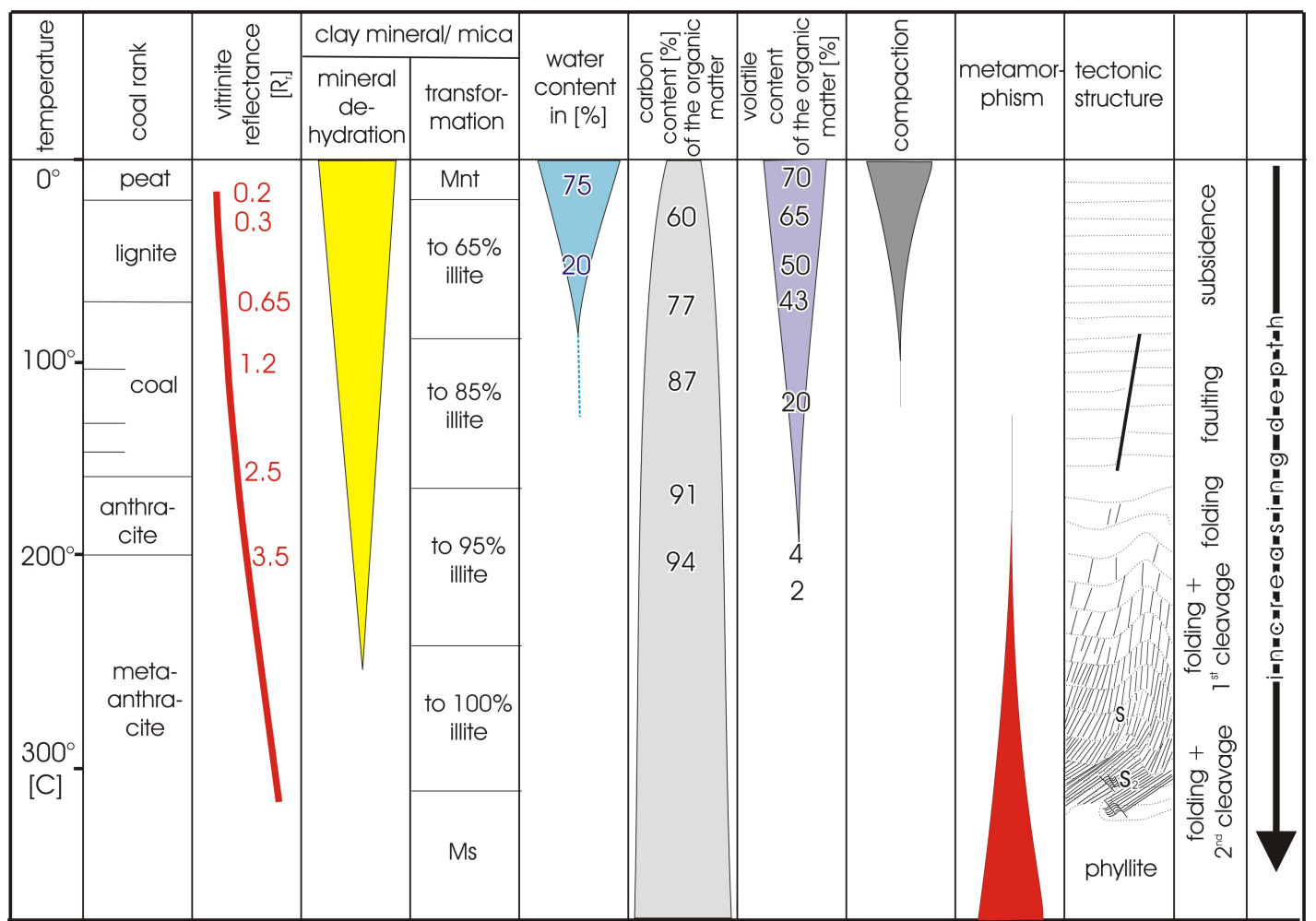

Fig. 1. Outline of coalification parameters and associated processes, partly based on Hoth (1997) $($ Mnt $=$ montmorillonite and Ms $=$ muscovite according to Kretz, 1982).

\section{Geological setting}

The mountains of the Verkhoyansk-Chersky fold belt in Eastern Yakutia (Fig. 2) are mostly composed of Palaeozoic and Mesozoic rock sequences which are intensely deformed by continental collision (Parfenov, 1984, 1991; Prokopiev, 1998; Oxman, 1998) and intruded by granitoids during Early Cretaceous time. According to Layer et al. (1993), Fujita et al. (1997) and Prokopiev (1998), isotopic ages from intrusions range in age from 120 to $140 \mathrm{Ma}$. Subsequent to sedimentary deposition and intrusive emplacement, fold deformation migrated symmetrically towards the forelands in the west or east, respectively (Prokopiev, 1998; Parfenov et al., 1995). The tectonic trend of compressive structures, including the intruded granitoids (Fig. 2), form an arc facing the Eurasian plate in the west. However, further to the north, the arc bends and is aligned in a west-east direction. The mountain ridges in this northern part often cross the compressive structures and are associated with faults of the Moma rift system (see references in Paech et al., 1998), which can be traced from the Laptev Sea to the south-western slope of the Ilin'-Tas Mountains along a distance of more than $1500 \mathrm{~km}$. The neotectonic Moma rift system is accompanied by many Tertiary basins, respectively grabens, the most important of which is the Moma graben along the Moma River
(Fig. 2). The current status of the stratigraphic age of the basins (Fig. 3) is compiled in Grinenko et al. (1989a, b) and Strepetova et al. (1981).

\section{Uyandina basin}

The Uyandina basin (Fig. 4) is elongated in north-south direction, and trends across the more or less east-west striking Mesozoic structures of the Polousny Ridge. The Uyandina basin, which is one of a number of intra-montane pullapart basins in the region, is $115 \mathrm{~km}$ long and up to $40 \mathrm{~km}$ wide. It is composed of Tertiary continental sedimentary rocks deposited in fluvial to lacustrine environment (Smetannikova et al., 1989). The sedimentary succession consists of weakly consolidated sand, silt, conglomerate and thin layers of lignite. Normally, their thickness is estimated to attain not more than $400 \mathrm{~m}$. The only borehole C-4960 (Fig. 4) penetrates $564 \mathrm{~m}$ and underlying basement is not reached (Smetannikova et al., 1989). In the northern part of the basin, the basement is Mesozoic in age. In the southern part of the basin, it consists of Palaeozoic rocks that were intensely deformed during the Late Mesozoic. Volcanic rocks occur locally, at the base of the Uyandina basin. On the eastern flank of the basin (Fig. 4) the volcanics consist of basaltic trachyandesite to trachyandesite, whereas on the western 


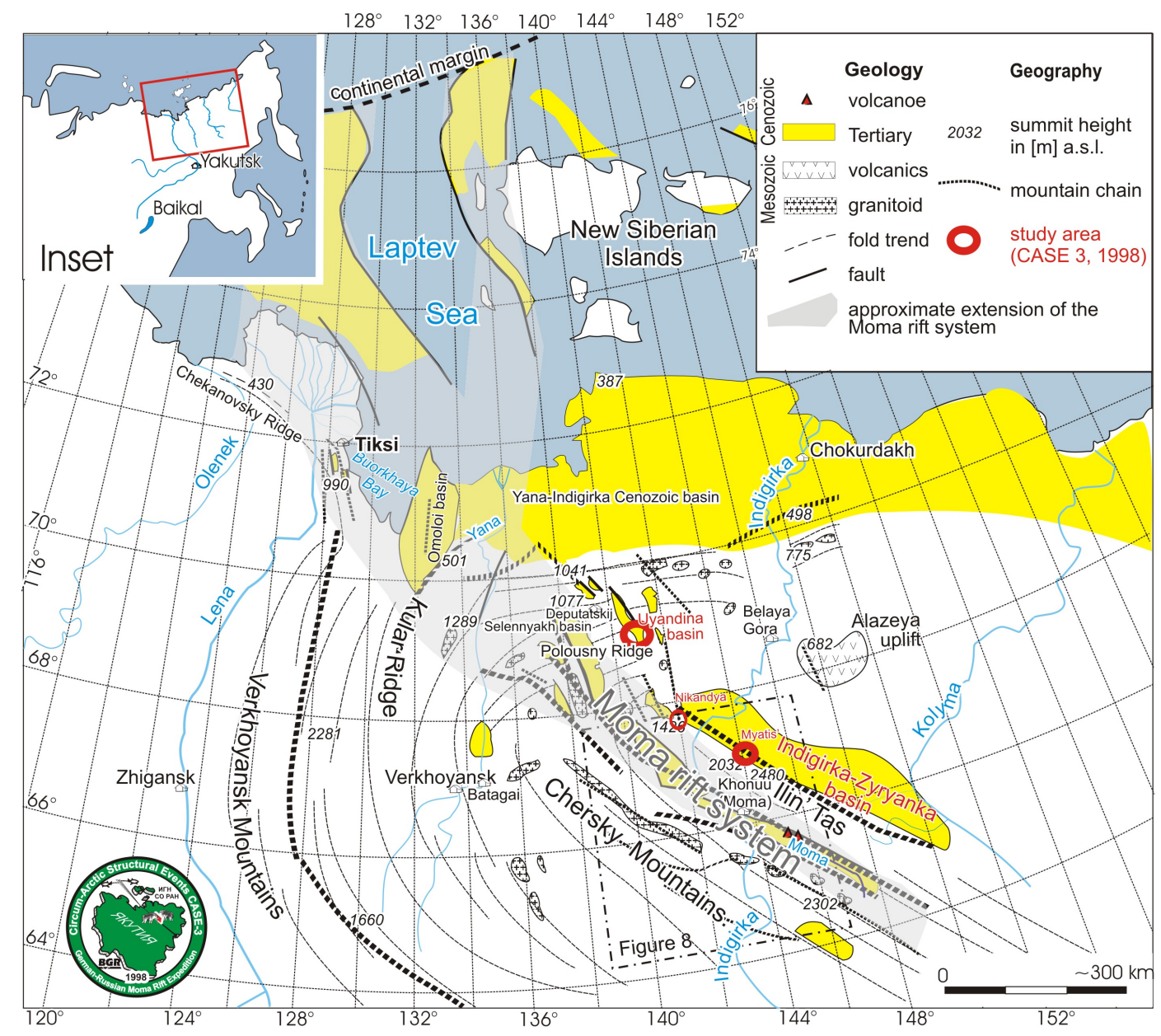

Fig. 2. Geography and geological overview of Alpine-aged tectonic structures of the Verkhoyansk-Chersky fold belt in eastern Yakutia.

flank of the basin, basalts form in flat-lying lava successions. Preliminary K-Ar isotopic data indicate that the trachyandesite formations are about $107 \mathrm{Ma}$ and the basalt formations are about $98 \mathrm{Ma}$ (F. Henjes-Kunst, personal communication, BGR, 2000); this age range is near the boundary of Early and Late Cretaceous. After a hiatus spanning the Late Cretaceous and most of the Palaeogene (Fig. 3), sedimentation restarts in Late Oligocene with the accumulation of finegrained, lignite-bearing, lacustrine sediments of the Elikchan Group. Subsequently, during the sedimentation of the Uyandina Group, sand and conglomerates formed in a fluvial environment. The Uyandina basin contains flat-lying sequences deformed by north-south striking faults that form grabens and half grabens separated by horsts. The outcrops visited in the Uyandina basin along the Inach River (Fig. 5) contain features that illustrate basin evolution: i.e., about $50 \mathrm{~m}$ thick clay to silt sections of the uppermost Elikchan Group, and thinner $(5 \mathrm{~m})$ conglomerate section of the entire Uyandina Group. Sedimentological features include widespread cross bedding and small-scale slumping or secondary tectonic compressive structures. The sands are often laterally displaced by conglomerate beds with pebbles up to $5 \mathrm{~cm}$ across. Cross bedding in sand and pebble imbrications in conglomerate reflect a varying transport direction, with an eastern direction prevailing. Locally, oriented wood fragments indicate E-NE to W-SW transport directions. The Inach conglomerate of Pleistocene age covers the Tertiary sequence. The tectonic structure of the Tertiary sedimentary rocks along the Inach River is characterized by flat-lying sequence that generally dips less than $20^{\circ}$ (Fig. 5). However, in narrow zones, sedimentary bedding has been structurally deformed. In these areas, the steeply dipping section is complicated by steeply inclined faults and many small-scale structures (Fig. 6a and b). These structures are believed to be the result of strike-slip movement along high angle faults, but normal fault movement also occurs. The orientation of tectonic elements varies considerably (Fig. 6c). Sedimentary bedding is mostly flat-lying; the stereonet data indicate a weakly expressed NE-SW tectonic trend. Where discernable, fault displacement is frequently strike-slip in character. The stereonet data indicate sinistral movement in the NE sector and dextral movement in the SE sector. During 


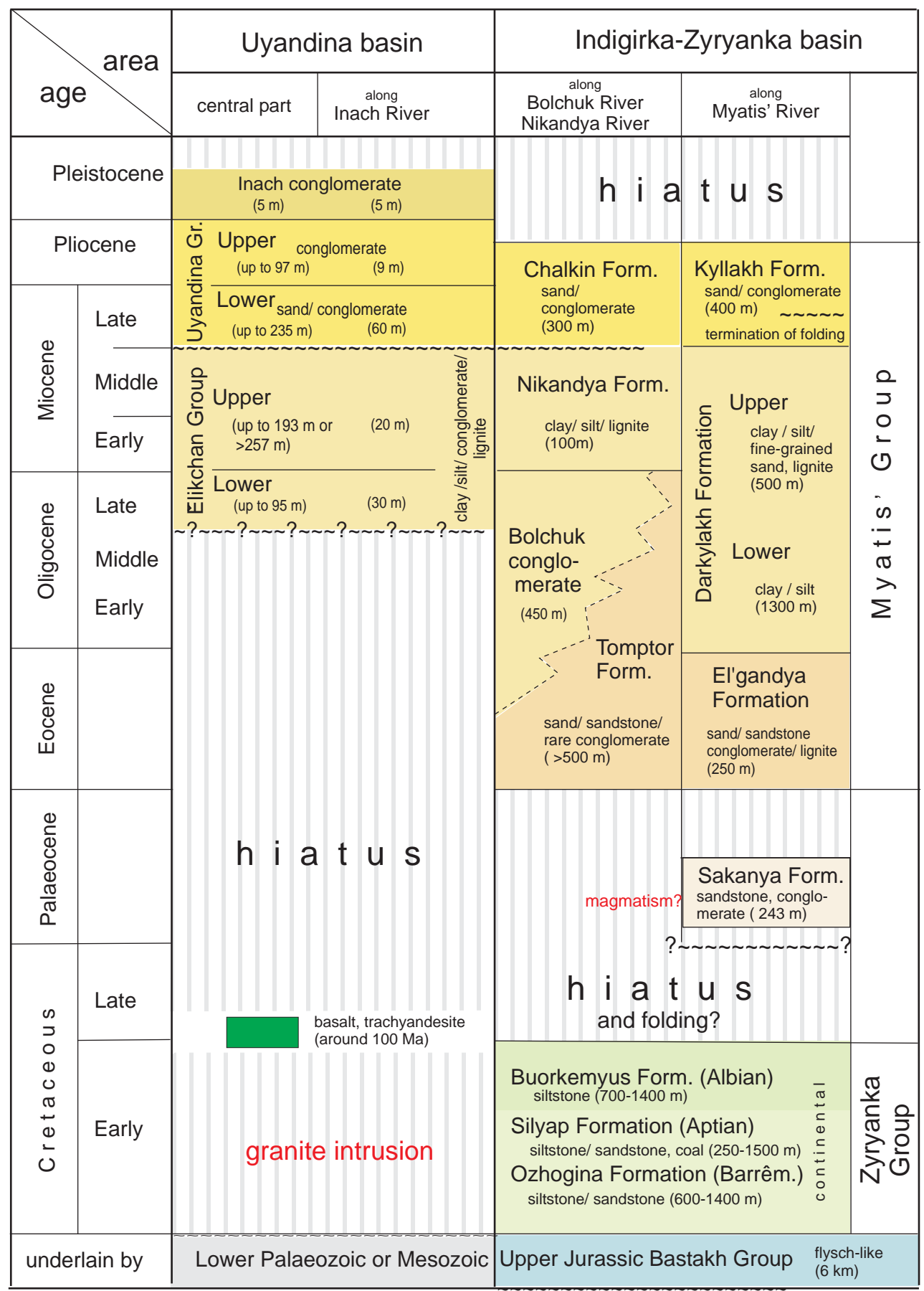

Fig. 3. Stratigraphic succession and lithology of Tertiary deposits in the basins studied in Yakutia (based on Grinenko et al., 1998a, b, 1999) $(\sim \sim \sim \sim \sim \sim$ means unconformity or disconformity).

fault activity, the sediments were probably water-saturated and irregular structures are the consequence, locally resembling slumping structures. The water saturation of the lignite intercalation caused the convolution of 5-m-scale in the north-eastern part of the section (Fig. 5, near sample site 1).
The tectonic data presented here differ from the explanation given by Imaev and Grinenko (1989) and Imaev et al. (1990). These workers believe that the entire sedimentary section has been deformed by thrust faults and folds oriented along a NE axial trend. Our data are in conflict with this interpretation. 
The immature, lignitic coal rank that our laboratory data reveal (Fig. 7 ; mean $=0.27 \% R_{r}$ ) suggests that a very low amount of subsidence has taken place in the basin - even for the older Tertiary sequence (Middle Miocene Elikchan Group, see Fig. 3).

\section{Indigirka-Zyryanka basin}

From Late Jurassic time the extended Moma-Zyryanka depocenter formed in the eastern part (rear zone of Prokopiev, 1998) of the Late Mesozoic Verkhoyansk-Chersky fold belt. The north-eastern part of the Moma-Zyryanka depocentre is also been referred to as the Indigirka-Zyryanka basin or simply Zyryanka basin (Prokopiev, 1998; Parfenov, 1991). Here, the sedimentation starts with Oxfordian marine volcanosedimentary sequences. The marine environment is characterized by a 6-km-thick; flysch-like rock section (Bastakh Group of Parfenov, 1991). In Cretaceous and Tertiary times (Fig. 3) the environment is continental (Grinenko et al., 1989a). The Cretaceous Zyryanka Group is largely composed of sandstones containing conglomerate and thin coal intercalations. Sedimentary rocks of Late Cretaceous age occur only locally. Tertiary sedimentation starts locally in Palaeocene time (Sakanya Formation in borehole 272-1) or later after the hiatus or the period of denudation, respectively. In general, the thickness decreases from the Ilin'-Tas anticlinorium towards the Alazeya uplift (Gajduk and Syundyukov, 1990).

Subsequent to the sedimentation the Moma-Zyryanka depocentre is subdivided by tectonic deformation in the Moma basin (now a graben) to the southwest, the Ilin'-Tas anticlinorium in the centre and the Indigirka-Zyryanka basin to the northeast (Fig. 8, Gajduk and Prokopiev, 1999). Rock units in the Ilin'-Tas anticlinorium are pervasively deformed. Development of intense cleavage in sedimentary strata is accompanied by southwest-directed thrust faulting onto the Moma basin and northeast-directed thrust faulting onto the Indigirka-Zyryanka basin.

The Indigirka-Zyryanka basin from the Ilin'-Tas anticlinorium in front of the Ilin'-Tas upthrust is asymmetrically zoned as follows: 1) a fold-and-thrust margin that deforms the Cretaceous sequences; 2) an internal zone characterized by deep subsidence and involving large-scale folding of thick, Tertiary sequences; and 3) an external zone facing the Alazeya uplift formed by Cretaceous volcanic rocks that rest unconformably on Jurassic rocks (Stavskij, 1981). In contrast, Parfenov (1991) describes Carboniferous to Lower Jurassic volcanoclastic sequences which are folded along a northeast-directed axial plane and unconformably overlain by flat lying Middle to Upper Jurassic clastic rocks. Geographically, the Ilin'-Tas is represented by mountain ranges of Alpine morphology attaining heights of more than $2000 \mathrm{~m}$ (Fig. 2). The fold-and-thrust margin and the internal zone of the Indigirka-Zyryanka basin underly a great extent of

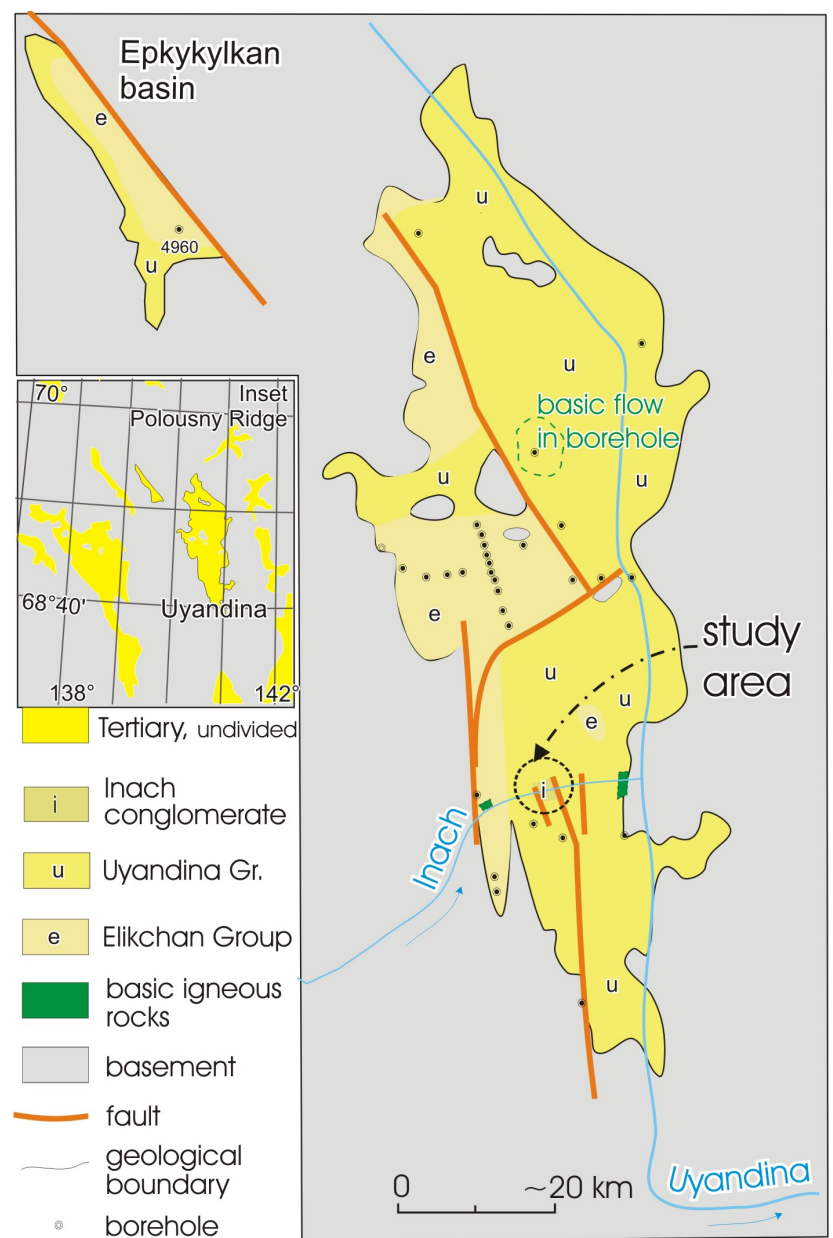

Fig. 4. Sketch map of the Uyandina basin and its environs.

the foothills of the Ilin'-Tas mountain range (Gajduk and Prokopiev, 1999). During the CASE-3 expedition the main study area in the Indigirka-Zyryanka basin was the excellent outcrops along the Myatis' River (Fig. 9). Outcrops along the Nikandya and Bolchuk Rivers were also studied. Along the Myatis' River, the exposures consist of: 1) the fold-and-thrust margin of the Cretaceous sequences to Eocene El'gandya Formation; and 2) more than $900 \mathrm{~m}$ of the Oligocene Lower Darkylakh Formation, which belongs to the internal part of the Indigirka-Zyryanka basin. The Cretaceous sedimentary rocks are characterized by NW-trending fold structures (see stereonet in Fig. 10), which have been deformed by a complicated duplex structure. The duplex detachment occurs within the relatively weak sequences of the Albian Buorkemyus Formation (Gajduk and Prokopiev, 1999). Calcite veinlets along thrust surfaces within the duplex structure are widespread (Fig. 10).

In contrast, the Tertiary sedimentary rock sequences reveal only strata steeply inclined to northeast. Evidently, this steep monoclinal inclination is the result of the upthrusting of the 


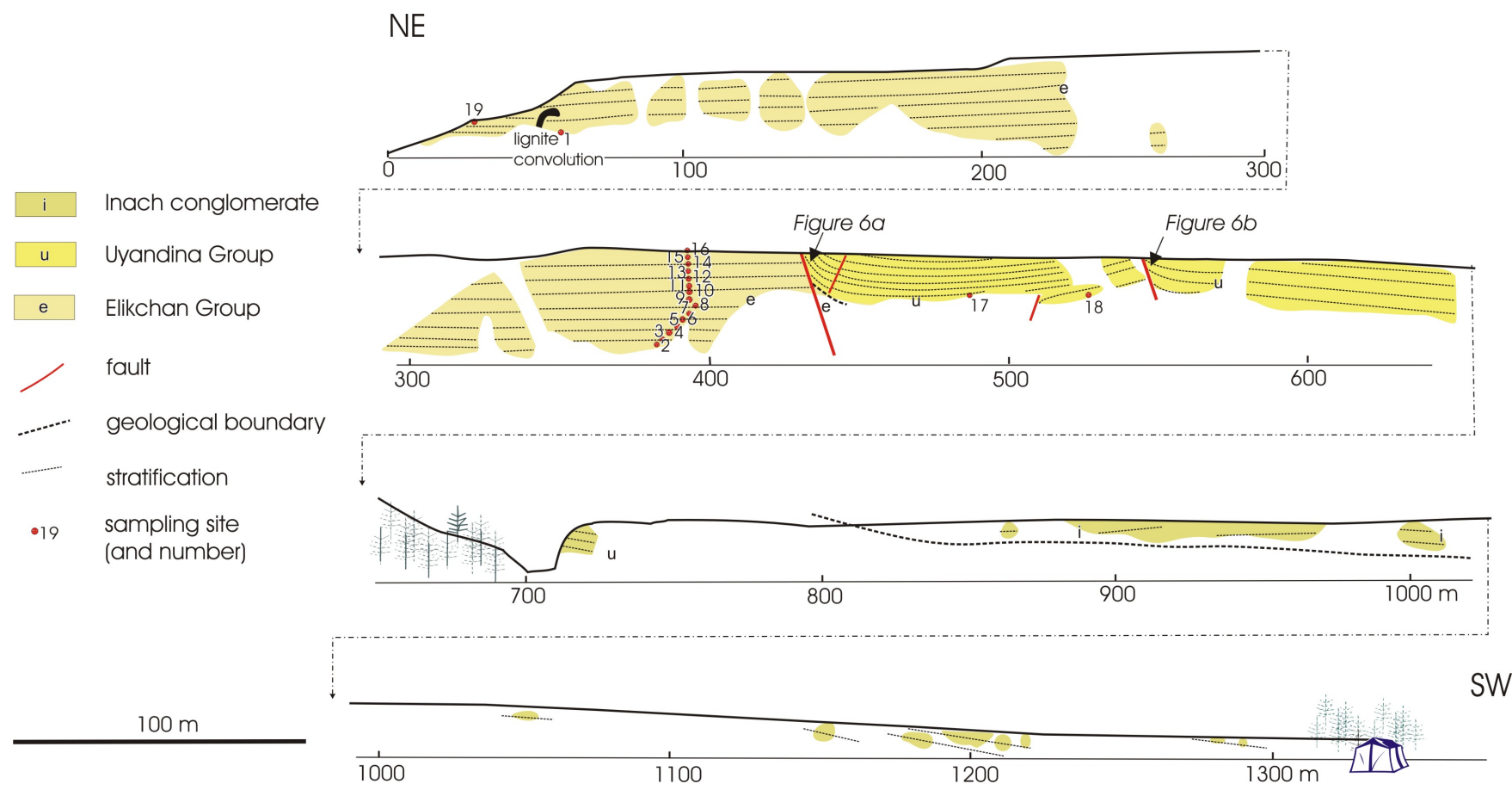

Fig. 5. Documentation of the Inach River outcrop in the Uyandina basin, general situation (for position of the outcrop see Fig. 4 and for age see Fig. 3).

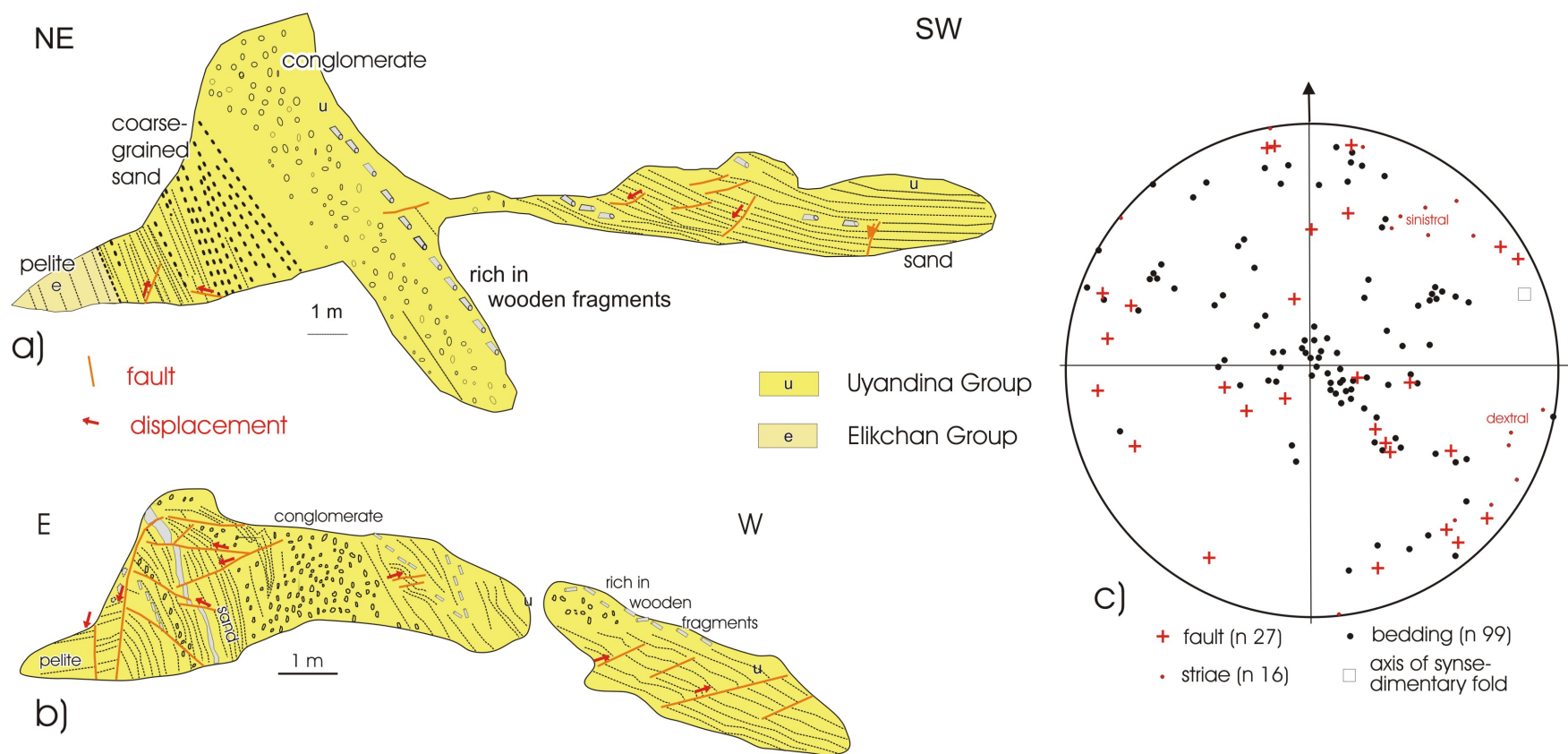

Fig. 6. Geological documentation of the Inach River outcrop in the Uyandina basin, small-scale structures: (a) and (b) in vertical sections: Detail of the sediments steeply inclined due to bending along faults (strike-slip mostly and normal) (for position see Fig. 4); (c) Tectonic elements in the stereonet (lower hemisphere). 


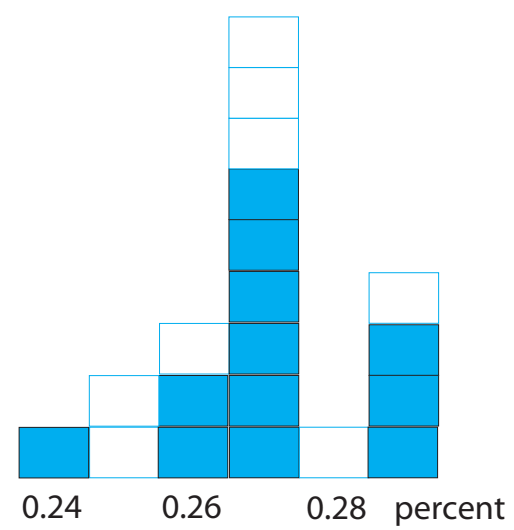

Fig. 7. Coalification (vitrinite reflectance $R_{r}$, in $\%$ ) in the Tertiary deposits of the Inach River outcrops (open rectangles = data of low quality).

fold-and-thrust margin which tilted or bent the thick Tertiary sequences. Locally, the deformation also affected the Upper Neogene Kyllakh Formation (Fig. 3) north of the outcrops studied along the Myatis' River (O. Grinenko, personal communication, 1998). There, a huge asymmetric syncline comprising the internal zone of the basin ascends gently in the direction of the Alazeya uplift. The tectonic observations of the Myatis' River outcrops compiled during the CASE-3 expedition are consistent with the data published by Imaev et al. (1990). However, our interpretations differ with those of the above referenced workers (see Sect. 6).

Coalification studies in the Myatis' River area can be based on results of Gajduk and Prokopiev (1999) and Syundyukov and Gajduk (1997). During CASE-3 expedition, additional and more detailed studies have been carried out (Fig. 11). The laboratory results indicate that higher coal rank occurs with increasing age. The vitrinite reflectance values increase from $0.24 \% R_{r}$ in the youngest sediments of the Darkylakh Formation (Oligocene) to $0.45 \% R_{r}$ at the base of Tertiary sequence. Stratigraphically deeper in the column of the Cretaceous strata the coal rank leaps up step-like to values of more than $0.5 \% R_{r}$. The step-like increase of the coal rank from Tertiary to Cretaceous sediments is typical in the Indigirka-Zyryanka basin (Fig. 12). Based on studies of the Myatis' River outcrops, increasing coal rank may be explained by thrusting (Gajduk and Prokopiev, 1999). However, in boreholes of the Indigirka-Zyryanka basin drilled away from the fold-and-thrust margin beneath the Tertiary the underlying sequences show rapidly increasing vitrinite reflectance values as compared to those in Tertiary deposits. An exception is the borehole 272-01 where the dramatic increase of coal rank from 0.3 to $0.7 \% R_{r}$ within $100 \mathrm{~m}$ is explained by coeval magmatism (Syundyukov and Gajduk, 1997). However, the occurrence of montmorillonite (Grinenko et al., 1999) conflicts with this interpretation. In borehole 272-03 high vitrinite reflectance values can be ex-

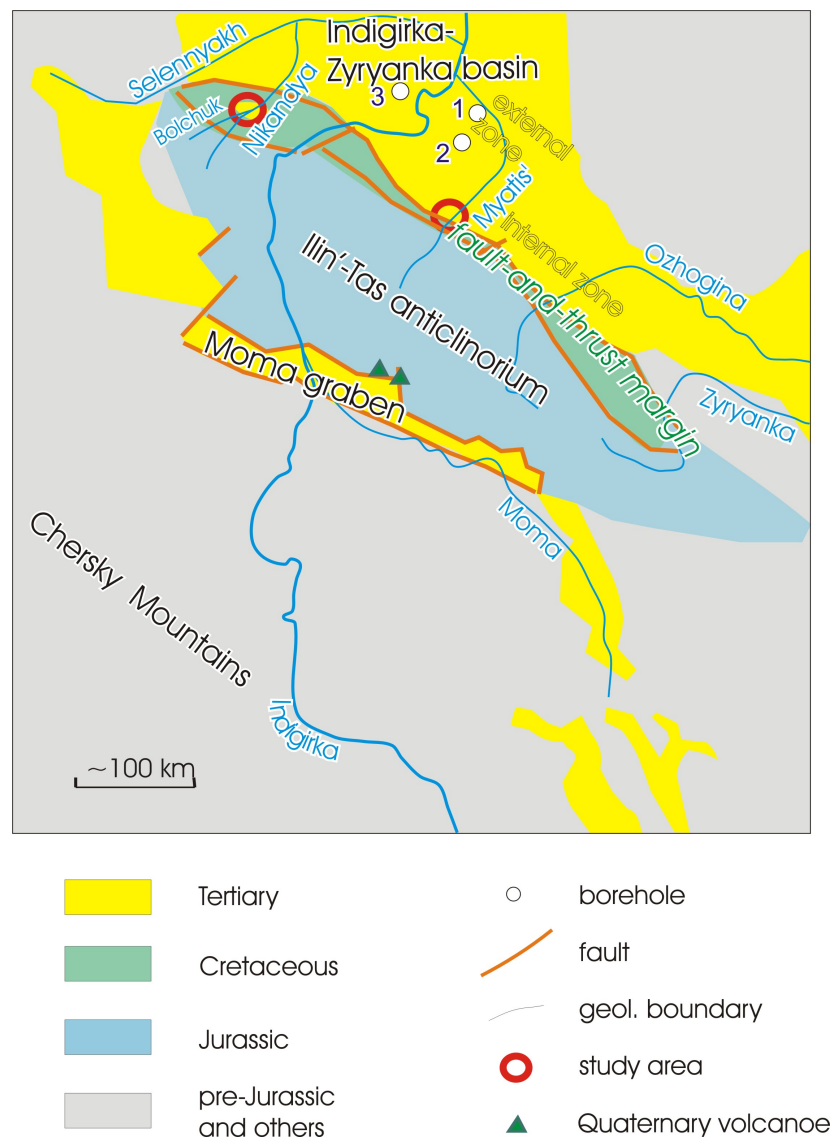

Fig. 8. Geological overview of the Moma-Zyryanka depocentre indicating its subsequently formed tectonic zones (borehole $1=272$ $01 ; 2=272-02 ; 3=272-03$, see Fig. 12; approximate position in NE Russia see Fig. 2).

plained by denudation which removed thick piles of Mesozoic sediments. This interpretation is reinforced by a tentatively assumed unconformity beneath the Tertiary deposits (Syundyukov and Gajduk, 1997).

Another aspect already mentioned by Gajduk and Prokopiev (1999) or Syundyukov and Gajduk (1997) is the increase of the coal rank (vitrinite reflectance values) from the external part of the Indigirka-Zyryanka basin to the internal portion of the basin including the fold-and-thrust margin, and to the Ilin'-Tas anticlinorium (Fig. 13). The coal rank increase reflects the effects of subsidence or overburden and tectonic deformation which are associated with higher temperatures in the Earth's crust. Tectonic deformation of the fold-and-thrust margin and the adjacent internal part of the Indigirka-Zyryanka basin was still taking place in Pliocene time (Gajduk et al., 1990, 1993; Imaev et al., 1998). The lower sequences of the Kyllakh Formation were still involved with the tectonic folding of the steep inner flank of the asymmetric syncline that formed in the sedimentary succession of the Indigirka-Zyryanka basin. Furthermore, within the foldand-thrust margin Pliocene sediments rest unconformably on 


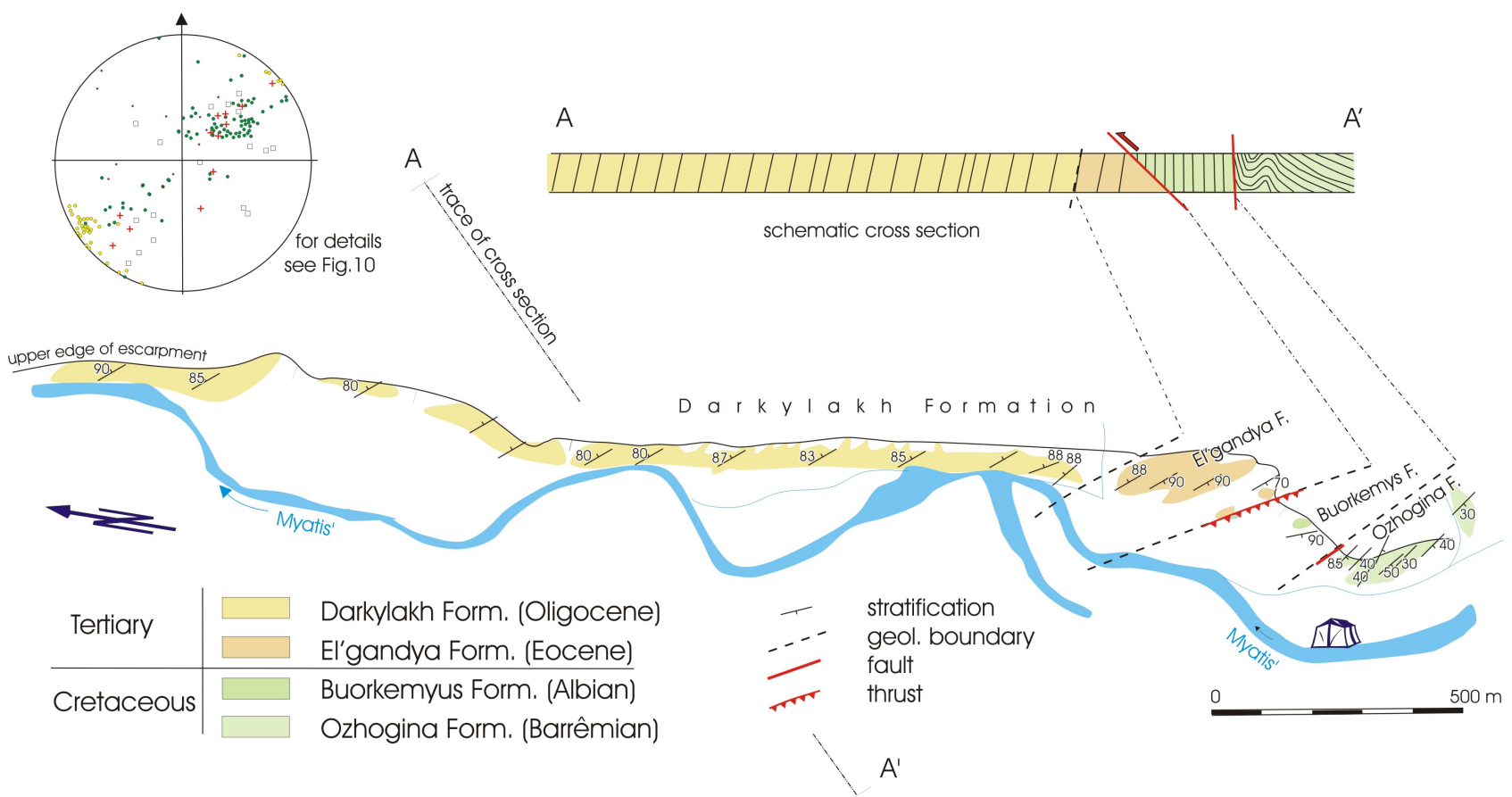

Fig. 9. Geological documentation of the Myatis' River outcrops revealing Cretaceous to Tertiary sequences.

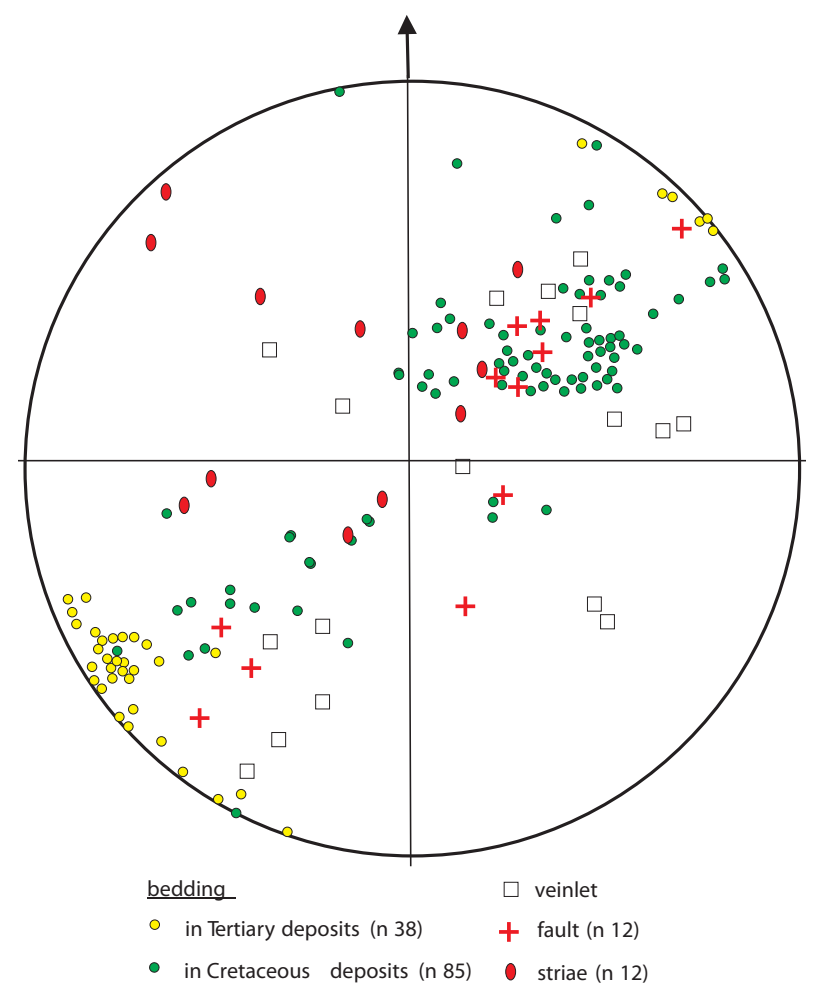

Fig. 10. Stereonet documentation (lower hemisphere) of tectonic data acquired along the Myatis' River outcrops (for geological setting see Fig. 9).
Lower Cretaceous sequences, which indicate a long hiatus in sedimentation. This unconformity is also reflected in coal rank data (Syundyukov and Gajduk, 1997). For example, in the Pliocene sequences the vitrinite reflectance value $\left(R_{r}\right)$ average $<0.4 \%$, in the underlying Cretaceous section average $1.6 \%$. Here, the estimation of the deformation age remains unclear. The wide-spread hiatus from Late Cretaceous to Early Palaeogene gives a time span long enough for considerable tectonic mobility Prokopiev (1998) assumes a wavelike propagation of the folding which migrates from the inner part of the Verkhoyansk-Chersky fold belt symmetrically to southwest or northeast in its rear zone, respectively. In the Moma-Zyryanka basin the folding starts in Late Jurassic and ends in Pliocene time. Thus, the folding of the Ilin'-Tas mountains may be Late Cretaceous to Early Palaeogene in age and in the rear zone the folding migrates in north-eastern direction and ends only in Pliocene time.

\section{Discussion and conclusion}

Despite the relatively small data set compiled during the CASE-3 Expedition involving two outcrop areas, the following conclusion can be given for the two basins which have completely different origins.

The Uyandina basin is associated with the Moma rift system. The rift runs from the Laptev Sea for more than $800 \mathrm{~km}$ into the Asian continent. Imaev and Grinenko (1989) described many outcrops along this rift system which show Cenozoic compressive structures, which are also seen in the 


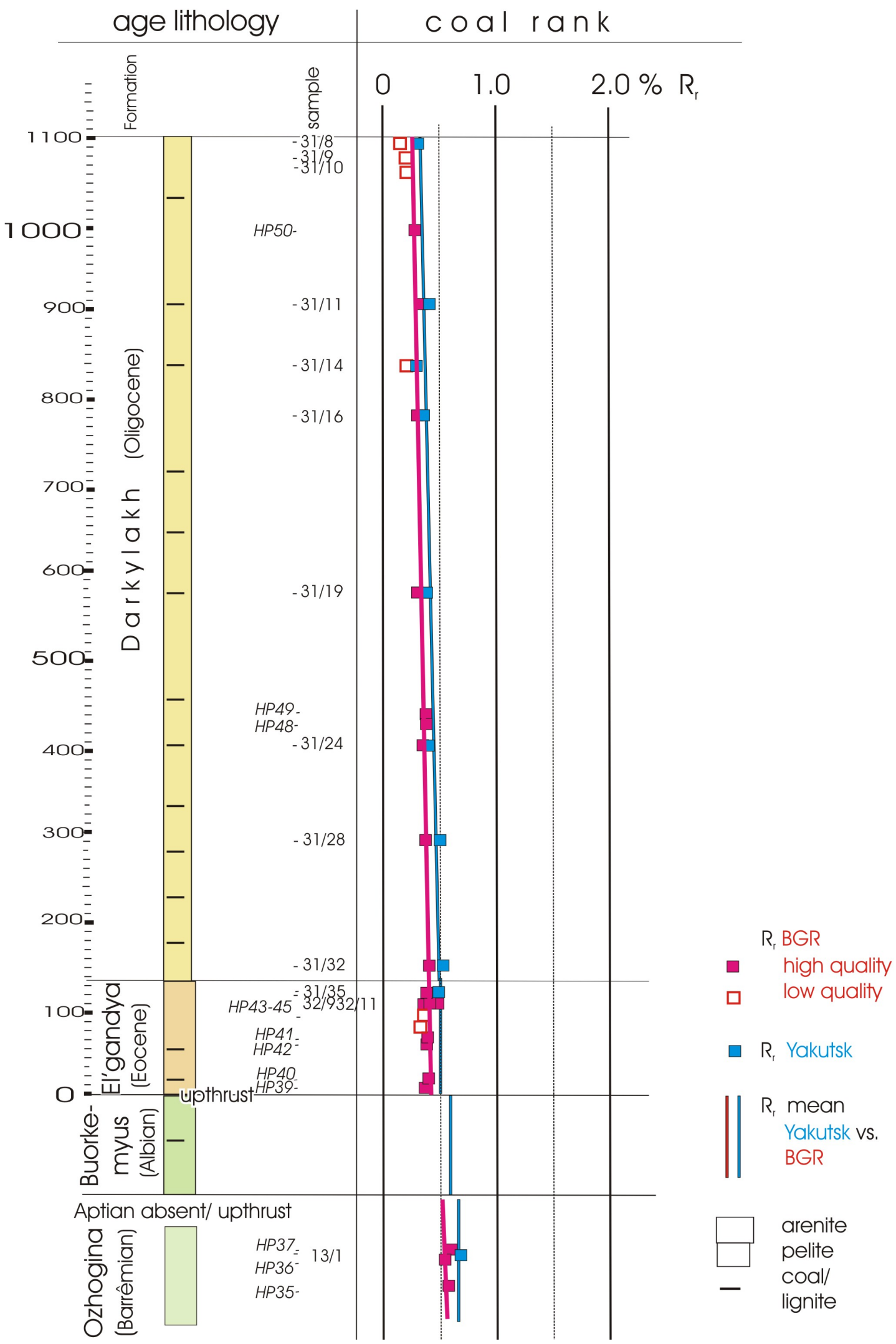

Fig. 11. Coal rank data (vitrinite reflectance $R_{r}$, in \%) of the outcrops at Myatis' River (for geological setting see Fig. 9; HP sample = German collection, numbers lacking letters $=$ Russian collection). 


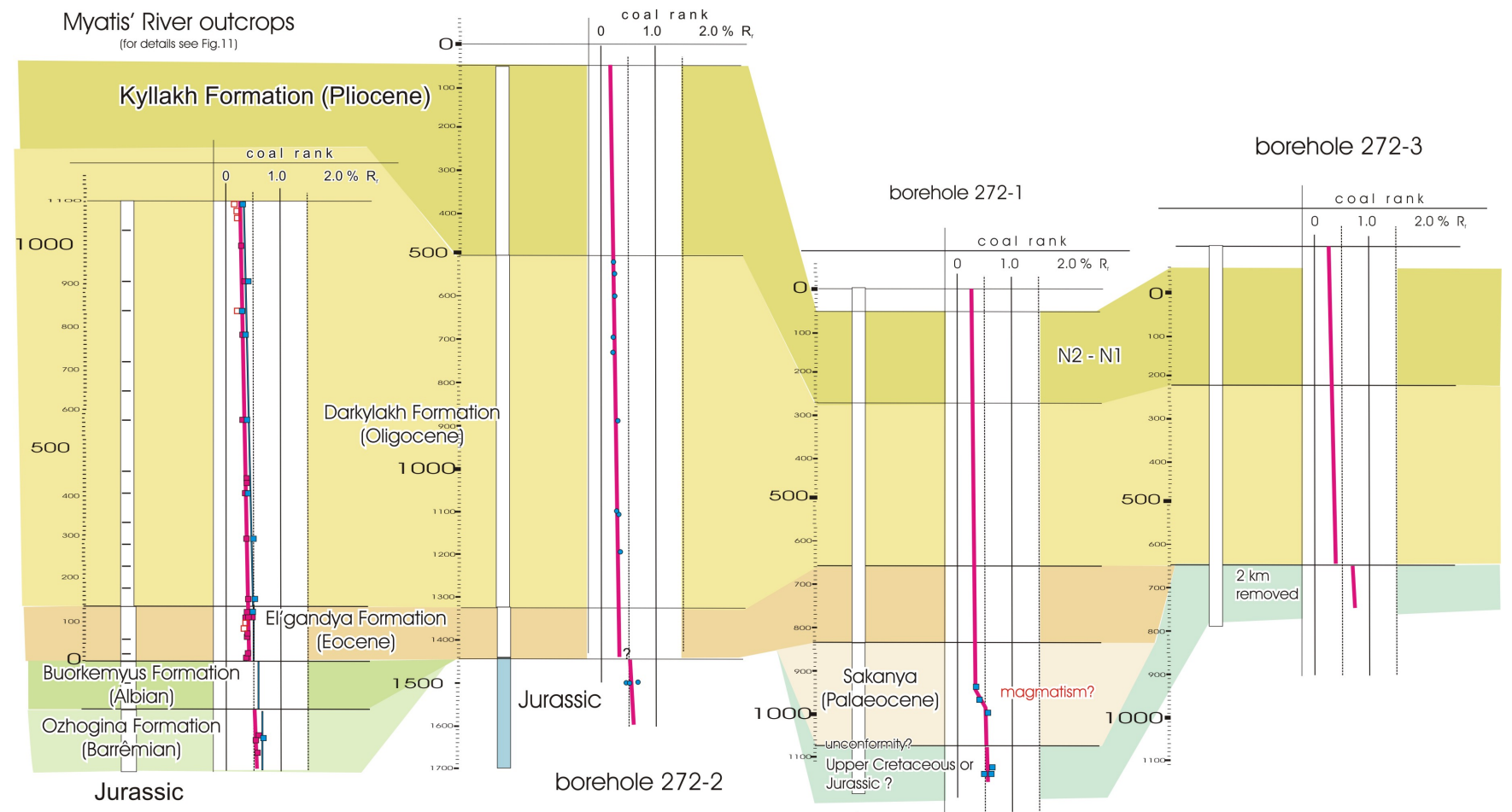

Fig. 12. Comparison of sedimentation or hiatus/folding? and coal rank $R_{r}$ (in \% (thick red line $=$ mean) in the Indigirka-Zyryanka basin (for references see text and for signs of coalification see Fig. 10 for well locations see Fig. 8).

\begin{tabular}{|c|c|c|c|c|c|c|c|}
\hline \multirow{3}{*}{\multicolumn{2}{|c|}{ formations }} & \multirow{3}{*}{ Ilin'-Tas } & \multicolumn{5}{|c|}{ Indigirka - Zyryanka basin } \\
\hline & & & \multirow{2}{*}{\multicolumn{2}{|c|}{$\begin{array}{cc}\text { fault-and-thrust margin } \\
\text { inner }\end{array}$}} & \multicolumn{2}{|c|}{ internal zone } & \multirow{2}{*}{$\begin{array}{l}\text { external } \\
\text { zone }\end{array}$} \\
\hline & & & & & inner part & outer part & \\
\hline \multicolumn{2}{|c|}{ Tertiary } & $<0.4$ (lignite) & \multicolumn{2}{|c|}{$<0.4$ (lignite) } & $\begin{array}{c}0.24-0.5 \\
\text { depending on depth }\end{array}$ & $\begin{array}{c}0.22-0.48 \\
\text { depending on depth }\end{array}$ & $\begin{array}{c}0.22-0.4 \\
\text { depending on depth }\end{array}$ \\
\hline \multicolumn{2}{|c|}{ Upper Cretaceous } & missing & \multicolumn{2}{|c|}{$\begin{array}{l}\text { missing } \\
\text { in Myatis area }\end{array}$} & 0.4 & 0.5 & missing \\
\hline \multirow{3}{*}{ 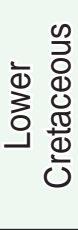 } & Buorkemyus F & missing & 1.0 & $\begin{array}{ll}- & 0.5 \\
& 0.55 \\
\end{array}$ & \multirow{3}{*}{0.55} & \multirow{3}{*}{0.5} & \multirow{3}{*}{ missing } \\
\hline & Silyap F & missing & 1.8 & - $\quad 0.7$ & & & \\
\hline & Ozhogina F. & missing & 2.9 & $\begin{array}{ll}- & 0.7 \\
& 0.59\end{array}$ & & & \\
\hline \multicolumn{2}{|c|}{ Jurassic } & $\begin{array}{r}2.4-5.2 \\
\mathbf{0 . 9}-1.7\end{array}$ & 0.54 & -3.0 & no data & 0.5 & 0.5 \\
\hline
\end{tabular}

Fig. 13. The horizontal and vertical trends of coal rank $R_{r}$ (in \%) in the sequences of the Indigirka-Zyryanka basin (for references see text; bold $=$ CASE-3 data).

Uyandina. The Uyandina basin history starts with the extrusion of basic or intermediate volcanic rocks most likely in an extensional regime at the boundary between Early to Late Cretaceous times. Following a sedimentary hiatus Tertiary sequences formed in pull-apart basins throughout the Polousny Ridge. The occurrence of strike-slip movements suggests a pull-apart mechanism along the faults which dis- place water saturated sediments which form only adjacent to the fault's secondary small fold structures. Primarly, the entire basin is an extensional structure. Because the outcrops studied experienced only minor subsidence, the coal rank ranges remain within the lignite field. Thus, the description of Imaev and Grinenko (1989) cannot be confirmed. 
In contrast, the geotectonic setting of the IndigirkaZyryanka basin is associated with the collision forming the Verkhoyansk-Chersky fold belt. It is located between the Precambrian Siberian platform in the west and the Jurassic Kolyma-Omolon microcontinent in the east (Parfenov, 1991; Prokopiev, 1998). The tectonic deformation starts in Early Cretaceous time in the central zone (Chersky Range) and propagates in both directions towards west and towards east where it continues in the Indigirka-Zyryanka basin until Pliocene time. The Indigirka-Zyryanka basin lies adjacent to this microcontinent and has much in common with a foredeep trough. The foredeep character is evidenced by asymmetric structure: the thickness of the basin deposits decreases towards east and the migration of the folding; the fold vergence of the fold and thrust movements and the deformation intensity decrease are respectively directed towards the Kolyma-Omolon microcontinent as well. Thus, the explanation given by Imaev et al. (1990) can only be confirmed inas-much-as the tectonic structures are compressive, but they are not associated with the Moma rift system. The coalification in the Indigirka-Zyryanka basin ranges from bituminous coal to lignite rank and reflects the maximal depth reached during its geological history. The decrease of the vitrinite reflectance in the Tertiary outcrops along the Myatis' River reveals that the coalification took place prior to the folding, tilting, and uplift of the fold-and-thrust margin during Pliocene time.

Evidently, the wide-spread hiatus prior to the Tertiary sedimentation suggests a period of high tectonic activity at the Cretaceous to Tertiary boundary.

Acknowledgements. The author is indebted to academician L. M. Parfenov for administrative support and to all members of the CASE-3 expedition, namely I. N. Belolyubskij, W. von Gosen, O. V. Grinenko, A. V. Prokopiev and L. Smetannikova for the fantastic cooperation in the field even under complicated conditions and for fruitful discussions. Thanks also go to J. Koch (Hannover) for the determination of the coal rank data and to I. S. Syundyukov (Yakutsk) for positioning of the Russian samples in the Myatis' River column (Fig. 11). The critical comments of the reviewer Boris Natal'in and Tom Bundtzen and of the editor David Stone are highly acknowledged, including the improvement of the English version.

\section{References}

Fujita, K., Stone, D. B., Layer, P. W., Parfenov, L. M., and Koz'min, B. M.: Cooperative program helps decipher tectonics of Northeastern Russia, Eos T. Am. Geophys. Un., 78(24), 252-253, 1997.

Gajduk, V. V., Grinenko, O. V.; Imaev, V. S., and Syundyukov, I.S.: Pozdnekajnozojskaya skladchatost' Ilin'-Tasskogo antiklinoriya (Verkhoyano- Kolymskaya skladchataya oblast') [Late Cenozoic folding of the Ilin'-Tas anticlinorium (Verkhoyan-Kolyma fold area)], Dokl. Akad. Nauk+, 312(2), 431-434, 1990.
Gajduk, V. V., Grinenko, O. V., and Syundyukov, I. S.: Vozrast skladchatosti Momo-Zyryanskoj vpadiny [The age of the folding in the Moma-Zyryanka basin], Tikhookean. Geol., 3, 99-108, 1993.

Gajduk, V. V. and Prokopiev, A. V.: Metody izucheniya skladchatonadvigovykh poyasov [Research methods in fold-and-thrust belts], Nauka Novosibirsk, 1999.

Gajduk, V. V. and Syundyukov, I. S.: Rekonstruktsiya moshchnostej verkhneyursko-kajnozoiskikh otlozhenij Indigirko-Zyryanskogo progiba [Reconstruction of thickness of the Upper Jurassic to Cenozoic sequences in the Indigirka-Zyryanka basin], in: Litologiya neftegazonosnykh i uglenosnykh otlozhenij Yakutii, Yakutsk Nauchnyj Tsentr, Sibir. Otdel. AN SSSR, Yakutsk, 5463, 1990 .

Grinenko, O. V., Gajduk V. V., and Fradkina, A. F., et al.: Indigirka-Zyryansky progib [Indigirka-Zyryanka basin], in: Paleogen i neogen Severo-Vostoka SSSR [Palaeogene and Neogene of northeastern USSR], edited by: Grinenko, O. V., Zharikova, L. P., Fradkina, A. F., et al., Yakutsk Nauchnyj Tsentr, Sibir. Otdel. AN SSSR Yakutsk, 90-105, 1989a.

Grinenko, O. V., Sergeenko, A. I., and Belolyubskij, I. N.: Paleogen i neogen Severo-Vostoka Rossii. Regional'naya stratigraficheskaya schema paleogenovykh i neogenovykh otlozhenij Severo-Vostoka Rossii i Ob'yasnitel'naya zapiska k nej. Chast' I, 20 pp. [Palaeogene and Neogene of northeastern Russia and explanatory notes, Part I, Yakutsk Nauchnyj Tsentr, Sibir. Otdel. Rossijskoj AN, Yakutsk, 1998a.

Grinenko, O. V., Sergeenko, A. I., and Belolyubskij, I. N.: Paleogen i neogen Severo-Vostoka Rossii. Regional'naya stratigraficheskaya schema paleogenovykh i neogenovykh otlozhenij Severo-Vostoka Rossii i Ob'yasnitel'naya zapiska k nej, Chast' II [Palaeogene and Neogene of northeastern Russia and explanatory notes, Part II], Yakutsk Nauchnyj Tsentr, Sibir. Otdel. Rossijskoj AN, Yakutsk, 1998b.

Grinenko, O. V., Sergeenko, A. I., and Belolyubskij, I. N.: Nizhnij paleotsen Momo-Zyryanskoj vpadiny [Lower Palaeocene of the Moma-Zyryanka basin], Otechestvennaya geologiya, 1999(4), 35-37, 1999.

Grinenko, O. V., Zharikova, L. P., Fradkina, A. F., et al.: Paleogen i neogen Severo-Vostoka SSSR [Palaeogene and Neogene of northeastern USSR], Yakutsk Nauchnyj Tsentr, Sibir. Otdel. AN SSSR, Yakutsk, 1989b.

Hoth, P.: Fazies und Diagenese von Präperm-Sedimenten der Geotraverse Harz - Rügen [Facies and diagenesis of pre-Permian deposits along the Geotraverse Hartz - Rügen], Schriftenreihe für Geowissenschaften, Berlin, 4, 1-139, 1997.

Imaev, V. S. and Grinenko, O. V.: Pozdnekajnozojskie nadvigi, vzbrosy i skladchatye dislokatsii Vostochnoj Yakutii [LateCenozoic thrusts, overthrusts and fold structures of eastern Yakutia], Dokl. Akad. Nauk+, Moskva, 307(2), 413-417, 1989.

Imaev, V. S., Imaeva, L. P., and Koz'min, B. M.: Aktivnye razlomy i seismotektonika Severo-Vostochnoj Yakutii [Active faults und seismotectonis in NE-Yakutia], Yakutsk Nauchnyj Tsentr, Sibir. Otd. AN SSSR, Yakutsk, 1990.

Imaev, V. S., Imaeva, L. P., and Koz'min, B. M.: Active faults and recent geodynamics of Yakutian seismic belts, Geotectonics, 28(2), 146-158, 1994 (English Translation).

Imaev, V. S., Imaeva, L. P., and Koz'min, B. M.: Seismotektonicheskie protsessy na granitse litosfernykh plit severo-vostoka Azii 
i Alyaski [Seismotectic processes at the boundary of the lithosphere plates of NE Azia and Alaska], Tikhookean. Geol., 172, 3-17, 1998.

Kretz, R.: Symbols for rock-forming minerals, Am. Mineral., 68(12), 277-279, 1983.

Layer, P. W., Parfenov, L. M., Surnin, A. A., and Timofeev V. F.: Pervye ${ }^{40} \mathrm{Ar}-{ }^{39} \mathrm{Ar}$ opredeleniya vozrasta magmaticheskikh i metamorficheskikh porod Verkhoyano-Kolymskikh mezozoid [First ${ }^{40} \mathrm{Ar}-{ }^{39} \mathrm{Ar}$ dating of magmatic and metamorphic rocks of Verkhoyansk-Kolyma Mesozoids], Doklady Rossijskoj Akademii Nauk, 329(5), 621-624, 1993.

Oxman, V. S.: Geodinamicheskaya evolyutsiya kollizionnogo poyasa gornoj sistemy Cherskogo (Severo-Vostok Azii) [Geodynamic evolution of the collisional belt of the Chersky Mountain system (Northeast Asia)], Geotektonika, 1, 56-69, 1998.

Paech, H.-J., Prokopiev, A. V., Gosen, W. V., Grinenko, O. V., Smetannikova, L. I., and Belolyubskij, I.: New results on the Moma rift and coeval structures in Yakutia, Polarforschung, 68, 59-63, 1998.

Parfenov, L. M.: Kontinetal'nye okrainy i ostrovnye dugi mezozoid Severo-Vostoka Azii [Continental margins and island arcs of the Mesozoids of northeastern Azia], Nauka, Novosibirsk, 1984.

Parfenov, L. M.: Tectonics of the Verkhoyansk-Kolyma Mesozoides in the context of plate tectonics, in: The achievements of plate tectonics in the USSR, edited by: Zonenshain, L. P., Tectonophysics, 199(2-4), 319-342, 1991.

Parfenov, L. M., Prokopiev, A. V., and Gaiduk, V. V.: Cretaceous frontal thrusts of the Verkhoyansk fold belt, eastern Siberia, Tectonics, 14(2), 342-358, 1995.
Prokopiev, A. V.: Verkhoyansk-Cherskij kollizionnyj orogen [Verkhoyansk-Chersky collisional orogen], Tikhookean. Geol., 17(5), 3-10, 1998.

Smetannikova, L. I., Stepanova, I. G., Grinenko, O. V., Zharikova, I. P., and Imaev, V. S.: Uyandinskaya vpadina [Uyandina basin], in: Paleogen i Neogen Severo-Vostoka SSSR [Palaeogene and Neogene of the northeastern USSR], edited by: Grinenko, O. V., Zharikova, L. P., Fradkina, A. F., et al., Yakutsk Nauchnyj Tsentr, Sibir. Otd. AN SSSR Yakutsk, 84-90, 1989.

Stach, E., Mackowsky, M.-T., Teichmüller, M., Taylor, G. H., Chandra, D., and Teichmüller, R.: Coal petrology, Berlin, Stuttgart, 1982.

Stavskij, A. P.: Melovoj magmatism i tektonika Alazejskogo ploskogoriya [Cretaceous magmatism and tectonics of the Alazeya highlands], Geotektonika, 1981(4), 90-103, 1981.

Strepetova, Z. V., Laukhin, S. A., Ryzhev, B. V., and Dubinchik, A. P.: Opornyj razrez kajnozoya na yano-omolojskom mezhdurech'e [Cenozoic key-section on Yana-Omoloi interstream area], Izv. AN SSSR, ser. geol., 1981(7), 48-63, 1981.

Syundyukov, I. S. and Gajduk, V. V.: Katagenez organicheskogo veshchestva mezo-kajnozojskikh otlozhenij IndigirkoZyryanskogo progiba (v svyazi s neftegazonosnost'yu), in: Geol. i geofizika 38, 4, 820-823, 1997; in translation: Catagenesis of organic matter in Meso-Cenozoic deposits of the IndigirkaZyryanka trough and their petroleum potential, Russ. Geol. Geophys.+, 38(4), 863-866, 1997. 